\title{
Optimisation of the PCR-invA primers for the detection of Salmonella in drinking and surface waters following a pre-cultivation step
}

\author{
KLM Moganedi1*, EMA Goyvaerts ${ }^{2}$, SN Venter $^{3}$ and MM Sibara ${ }^{4}$ \\ ${ }^{1}$ Department of Microbiology, University of Limpopo, Private Bag X1106, Sovenga, 0727, South Africa \\ ${ }^{2}$ Kitso Biotech Pty Ltd, 23 Fernvilla P1, Pietermaritzburg 3201, South Africa \\ ${ }^{3}$ Department of Microbiology and Plant Pathology. University of Pretoria, Pretoria 0002, South Africa \\ ${ }^{4}$ Department of Education, Private Bag X603, Pretoria 0001, South Africa
}

\begin{abstract}
A polymerase chain reaction (PCR)-based method for the detection of Salmonella species in water samples was optimised and evaluated for speed, specificity and sensitivity. Optimisation of $\mathrm{Mg}^{2+}$ and primer concentrations and cycling parameters increased the sensitivity and limit of detection of PCR to $2.6 \times 10^{4} \mathrm{cfu} / \mathrm{m} \ell$. A $6 \mathrm{~h}$ non-selective pre-enrichment step further increased the limit of detection to $26 \mathrm{cfu} / \mathrm{m} \ell$. Out of 14 different Salmonella strains tested, only two, Salmonella arizonae and Salmonella pullorum, did not give positive amplification results with primers homologous to a conserved region of the invA gene. When environmental and drinking waters were assessed, a non-selective pre-enrichment step was included to increase the detection efficiency of PCR. The PCR method demonstrated specificity in the presence of other competing micro-organisms as confirmed by the conventional culture method. No false positives or negatives were observed when household and environmental water samples were tested by invA-PCR analysis parallel to the culture method.
\end{abstract}

Keywords: water quality, Salmonella, PCR, invA primers

\section{Introduction}

The availability of safe water remains an urgent human need in many countries and has barely kept pace with population growth. Globally, water is abundant but it is not always available in potable form to many people. One third of the population in the developing countries suffers serious diseases and fatalities due to unhealthy environment and Africa is most vulnerable to waterborne diseases and death due to unsafe drinking water. South Africans who lack access to potable water account for $17 \%$ of the population (The Water Wheel, 2006), and this water scarcity leads to usage of water sources such as dams, pools, rivers and unprotected springs that pose a health risk to the human population (Obi et al., 2002).

Water sources are often polluted with sewage runoff and become the main causes of diseases such as typhoid and cholera as a result of lack of sanitation facilities. A study funded by Water Research Commission (WRC) revealed the predominance of Salmonella in the environment which could possibly be due to faecal contamination from human and animal excreta (Lehloesa and Muyima, 2000 and The Water Wheel, 2006). An outbreak of typhoid fever that occurred between August and October 2006 in Mpumalanga, RSA, has resulted in four deaths and 600 people infected. Typhoid fever has become endemic in RSA though at a low frequency (The Water Wheel, 2005). In 1997 there were 17 deaths out of 451 cases reported; $93.8 \%$ of these were Africans who were 15 years and older and again $25 \%$ of these cases were reported in the less populated Limpopo Province (Depart-

\footnotetext{
* To whom all correspondence should be addressed.

䱾 +27 15268 2996/2429; fax: +27 15268 3012/3234;

e-mail: kgabom@ul.ac.za

Received 30 September 2005; accepted in revised form 4 December 2006.
}

ment of Health, 1998). In 1996, 643 cases and 11 deaths were reported in RSA due to typhoid fever. In 2001, 117147 cases of cholera with 265 fatalities were reported in the RSA (Nevondo and Cloete, 2002; The Water Wheel, 2005), whereas 35 cases were reported in 2004 (Water Services: National Information System, 2006). The high level of microbial contamination that South African water resources receives due to lack of proper sanitary facilities makes routine detection of Salmonella spp. in environmental samples a necessary direct component of any public health strategy.

A number of methods for detecting Salmonella have been published. Immunoassays and PCR-based methods are currently the dominant methods used for the detection of bacterial pathogens. Immunoassays generally have a problem of cross-reactivity which produce false positives (Mansfield and Forsythe, 2000; Caruso et al., 2000, Liu et al., 2001; Walker et al., 2001 and Fratamico, 2003). Furthermore, immunoassays inherently have a high detection limit even when pre-enrichment of between 18 to $30 \mathrm{~h}$ is included in the assay (Jaradat et al., 2004; Liu et al., 2001; Chen and Durst, 2006 and De Medici et al., 1998) and this would more often produce false negatives if the level of Salmonella is low.

PCR offers a more rapid and reliable method for the detection of Salmonella in natural environments. The assay combines simplicity with specificity and sensitivity in detecting organisms. PCR assay has been used successfully to diagnose the presence of bacterial pathogens in aquatic environments, food products and clinical samples (Chen and Griffiths, 2001; Ellingson et al., 2004; Guo et al., 2000; Myint et al., 2006; Patel et al., 2006; Sandery et al., 1996; Schrank et al., 2001; Soumet et al., 1999(a); Soumet et al., 1999(b)). The PCR assay can detect minute amount of the target DNA sequence, however this sensitivity can be influenced by physical dilution in aquatic environments and food products and may result in Salmonella escaping 
detection. Pre-enrichment of samples is thus necessary to lower the detection limit and dilute any inhibitory substances present in the samples. Most PCR assays carried out currently include a minimum of 6 to $8 \mathrm{~h}$ pre-cultivation step (Ellingson et al., 2004; Fratamico, 2003; Guo et al., 2000; Myint et al., 2006; Oliveira et al., 2002; Oliveira et al., 2003; Patel et al., 2006; Wang and Yeh, 2002) that can increase the sensitivity to one digit number of CFU, which is much better than the immunoassays that preenrich the samples for 24 to $30 \mathrm{~h}$ but still obtain minimum detection limits of $10^{3}$ CFU (Soumet et al., 1999(a); Liu et al., 2001; Chen and Durst, 2006).

Rahn et al. (1992) reported the invA primer set that was able to discriminate between Salmonella and non-Salmonella species. They achieved a low detection limit $(300 \mathrm{cfu} / \mathrm{m} \ell)$ but did not evaluate the method on environmental samples. This current study extends the work done by Rahn et al. (1992) by assessing the efficacy of these invA primers in detecting Salmonella in natural water systems following optimisation of the PCR conditions. A cultivation step prior to PCR was added to circumvent the problem of detecting dead cells.

\section{Materials and methods}

Salmonella enteritidis ATCC 13076 was used as a positive control. Bacterial strains used to determine the specificity of PCR primers are listed in Table 1. Cultures were maintained on nutrient agar (Oxoid) plates and slants.

Primers and probe. A 284 bp region of the Salmonella invA gene (Galan et al., 1992) was amplified by the primers Sal 1 (5'-GTGAAATTATCGCCACGTTCGGGCAA) and Sal 2 (5'TCATCGCACCGTCAAAGGAACC) designed by Rahn et al. (1992). The identity of the amplicons was confirmed by hybridisation to an internal probe Sal 3 (5'-GCCCGGTAAACAGATGAGTATTGA) designed by Gericke and Kfir (1995). The primers and probe were purchased from University of Cape Town.

\section{Template preparation}

Boiling method: S. enteritidis ATCC 13076 was incubated at $37^{\circ} \mathrm{C}$ overnight on nutrient agar plates. Thereafter, a colony from the plate was suspended in $1 \mathrm{~m} \ell$ of sterilised distilled water in a $2 \mathrm{~m} \ell$ micro-centrifuge tube and boiled for $10 \mathrm{~min}$. The lysate was chilled on ice and then spun for $5 \mathrm{~min}$ in a micro-centrifuge at high speed to pellet the debris. Five $\mu \ell$ of the supernatant was used as template in the PCR reaction.

Single colony method: A colony from an overnight culture of S. enteritidis ATCC 13076 was suspended in $1 \mathrm{~m} \ell$ of sterile distilled water, and not boiled. Tenfold serial dilutions were prepared and $5 \mu \ell$ thereof was added directly to the PCR reaction mix. Another $5 \mu \ell$ was plated on nutrient agar for a bacterial count.

Total DNA isolation method: The procedure followed was a combination with modification of the methods of Marmur (1961) and Wallace (1987). Briefly, S. enteritidis was grown overnight in $500 \mathrm{~m} \ell$ nutrient broth at $37^{\circ} \mathrm{C}$. The cells were pelleted in $50 \mathrm{~m} \ell$ tubes and resuspended in $20 \mathrm{~m} \ell$ proteinase $\mathrm{K}$ reaction buffer $[10 \mathrm{mM}$ Tris, pH 7.8; 5mM EDTA and $0.5 \%$ sodium dodecyl sulphate (SDS)]. An additional SDS (1.5\%) was added and the suspension was incubated at $37^{\circ} \mathrm{C}$ for $1 \mathrm{~h}$. RNase $\mathrm{A}$ $(50 \mu \mathrm{g} / \mathrm{m} \ell)$ and proteinase $\mathrm{K}(100 \mu \mathrm{g} / \mathrm{m} \ell)$ were added successively and the lysate was incubated at $37^{\circ} \mathrm{C}$ for $20 \mathrm{~min}$ and $1 \mathrm{~h}$, respectively. The mixture was sequentially extracted with equal volumes of phenol: chloroform: isoamyl alcohol (24:24:1), chloroform: isoamyl alcohol (24:1) and water-saturated diethyl ether. The upper phase was removed in between extractions and transferred to a new tube. DNA was precipitated with 2 vols ethanol and $0.2 \mathrm{M} \mathrm{NaCl}(\mathrm{pH} 8.0)$. The DNA pellet was dissolved in sterile distilled water and quantified by UV spectrophotometry at 260 and $280 \mathrm{~nm}$. Tenfold serial dilutions with sterile distilled water were performed and $5 \mu \ell$ from each dilution was added to the $\mathrm{PCR}$ reaction mixture.

\section{PCR optimisation}

The PCR reaction mixture for the reference PCR protocol consisted of PCR buffer (50 mM KCl, $10 \mathrm{mM}$ Tris-Cl (pH 9), 0.1\% Triton ${ }^{\circledR} \mathrm{X}-100$ ), 1.5U Taq DNA polymerase (Promega), $1.5 \mathrm{mM}$ $\mathrm{MgCl}_{2}, 200 \mathrm{ng}$ of each primer and $100 \mu \mathrm{M}$ each of dNTPs. The PCR cycling conditions were: denaturation at $94^{\circ} \mathrm{C}$ for $1 \mathrm{~min}$, primer annealing at $55^{\circ} \mathrm{C}$ for $1.5 \mathrm{~min}$ and extension at $72^{\circ} \mathrm{C}$ for $1.5 \mathrm{~min}$ for a total of 30 cycles, followed by a $7 \mathrm{~min}$ extension period. Amplification was performed in a GeneAmp PCR 2400 version 2.11 thermocycler (Perkin Elmer). Optimisation was performed in duplicate. Parameters that were varied were $\mathrm{MgCl}_{2}$ concentration ( 0 to $4 \mathrm{mM}, \Delta=0.5 \mathrm{mM}$ ), primer concentration $(0$ to $200 \mathrm{ng}, \Delta=25 \mathrm{ng}$ ), annealing temperature $\left(55\right.$ to $\left.65^{\circ} \mathrm{C}, \Delta=1^{\circ} \mathrm{C}\right)$ and incubation period ( 30 to $180 \mathrm{~s}, \Delta=30 \mathrm{~s}$ ) and lastly extension period ( 0 to $300 \mathrm{~s}, \Delta=60 \mathrm{~s}$ ). Each component, in the listed order, was optimised while others were kept constant and the optimised parameter was thereafter used in subsequent experiments.

\section{Limit of detection}

Cell dilution: Tenfold serial cell dilutions of S. enteritidis ATCC 13076 from $10^{0}$ to $10^{5}$ were prepared by the single colony method. Five $\mu \ell$ from dilutions that gave negative amplification results were added to nutrient broth and incubated for $6 \mathrm{~h}$ at $37^{\circ} \mathrm{C}$.

DNA dilution: A $5 \mu \ell$ aliquot of each dilution ( $30 \mathrm{pg}$ to $3 \mu \mathrm{g} / \mathrm{m} \ell$ ) of the total DNA of $S$. enteritidis was added to the PCR mixture and the optimised PCR protocol was followed.

\section{Specificity}

S. enteritidis ATCC 13076 served as a positive control and a no-template negative control was included to monitor contamination. DNA of all the Salmonella and non-Salmonella strains (Table 1) was extracted by the boiling method. PCR products were verified by Southern hybridisation with Sal 3 probe. The probe was Dig-11-dUTP labelled (Roche-Diagnostics). Southern transfer of amplicons onto a nylon membrane was carried out as outlined in Sambrook et al. (1989). Hybridisation of the probe to the amplicons was detected with CDP-Star ${ }^{\mathrm{TM}}$ according to manufacturer's guidelines (Dig System User's Guide for Filter Hybridisation, 1995).

\section{Field sampling}

A total of 39 water samples $(2 \times 50 \mathrm{~m} \ell$ each) were collected from household and communal taps (17), storage tanks (10) and rivers (12) from Kgapane, Mamabolo and Venda areas in the Limpopo Province, RSA. Tap water was allowed to run for $10 \mathrm{~s}$ before collection into Sterilin bottles. Water from the storage tanks and rivers (both still and running water) was collected $200 \mathrm{~mm}$ below the surface. All the water samples were kept on ice. The 


\begin{tabular}{|c|c|c|c|}
\hline \multicolumn{4}{|c|}{$\begin{array}{l}\text { TABLE } 1 \\
\text { Bacterial strains analysed with the PCR invA - primer technique }\end{array}$} \\
\hline Culture & Selection criteria & Culture & Selection criteria \\
\hline \multirow[t]{3}{*}{$\begin{array}{l}\text { Salmonella enteritidis ATCC } \\
13076\end{array}$} & \multirow[t]{3}{*}{ Positive control } & $\begin{array}{l}\text { Escherichia coli } O: 112 \\
\text { E. coli O:29 } \\
\text { E. coli O:143 } \\
\text { E. hermanii }\end{array}$ & * $45 \%$ DNA relatedness to Salmonella \\
\hline & & Klebsiella pneumoniae & $* 40 \%$ relatedness to Salmonella \\
\hline & & Citrobacter freundii & $* 50 \%$ relatedness to Salmonella \\
\hline \multirow{3}{*}{$\begin{array}{l}\text { S. paratyphi CCRC } 12949 \\
\text { S. typhimurium } \\
\text { S. typhi } \\
\text { S. saintpaul } \\
\text { S. Dublin } \\
\text { S. oxford } \\
\text { S. bloemfontein } \\
\text { S. derby } \\
\text { S. pullorum } \\
\text { S. arizonae } \\
\text { S. agona }\end{array}$} & \multirow[t]{3}{*}{$\begin{array}{l}\text { Determination of con- } \\
\text { servation of the invA } \\
\text { gene within Salmonella } \\
\text { species }\end{array}$} & $\begin{array}{l}\text { Shigella dysentery } \\
\text { S. sonnei } \\
\text { S. flexneri } \\
\text { S. boydii }\end{array}$ & *45\% DNA relatedness to Salmonella \\
\hline & & Pseudomonas aeruginosa & $\begin{array}{l}\text { **reported to produce non-specific prod- } \\
\text { uct with invA primers }\end{array}$ \\
\hline & & $\begin{array}{l}\text { Bacillus cereus } \\
\text { B. cereus var mycoides }\end{array}$ & $\begin{array}{l}\text { **reported to give non-specific product } \\
\text { with invA primers }\end{array}$ \\
\hline
\end{tabular}

Source: All the micro-organisms were obtained from Environmentek, CSIR.

*: Bergey's Manual of Systematic Bacteriology (1984 - 1989).

**: Rahn et al. (1992)

samples were assessed in duplicates, using the PCR technique and the conventional culture method SANS 6340 (2004). Most probable number (MPN) was determined from each sample. For PCR analysis, water samples $(50 \mathrm{~m} \ell)$ were centrifuged and the pellets were suspended in $1 \mathrm{~m} \ell$ sterile distilled water. A $5 \mu \ell$ aliquot from each suspension was added directly to the PCR reaction mixture.

Multiple tube fermentation was performed with buffered peptone water (BPW-Biolab) and Rappaport Vassiliadis broth (RV-Merck) as non-selective and selective enrichment media, respectively. Three series of three BPW tubes containing inverted Durham tubes were inoculated with 10,1 and $0.1 \mathrm{~m} \ell$ of each sample and were incubated at $36^{\circ} \mathrm{C}$ for $6 \mathrm{~h}$. RV broth was inoculated with 1:10 or 1:100 of BPW culture if the culture has little growth or is turbid, respectively. The cultures were incubated at $43^{\circ} \mathrm{C}$ for $24 \mathrm{~h}$. MPN of each sample in three replicates was determined and PCR was run from one tube of the three series of BPW tubes, i.e., one PCR reaction/sample, and also from the RV broth. For confirmation of presence of Salmonella, xylose lysine deoxycholate (XLD-oxoid) and BGA (modified brilliant green agar-oxoid) were inoculated with a loopful of RV broth culture and the plates were incubated at $35^{\circ} \mathrm{C}$ for $24 \mathrm{~h}$. Red colonies with or without black centres (typical Salmonella colonial appearance) were further tested with API 20E and PCR. Samples that were confirmed biochemically by API $20 \mathrm{E}$ and produced a $284 \mathrm{bp}$ fragment with PCR were regarded as positive for Salmonella. The MPN value was obtained from the probability table (SANS 8199, 2006).

PCR products were verified by probing with Sal 3. The 284 bp bands were cut out from the low melting agarose gel and suspended in 2 vols of sterile distilled water. The gels were incubated at $65^{\circ} \mathrm{C}$ to melt the gel, and then spun for $5 \mathrm{~min}$. An aliquot of $10 \mu \ell$ of heat-denatured PCR products of each sample was dotted on a positively charged nylon membrane and hybridised to the Dig end-labelled Sal 3 probe.

\section{Results}

Optimisation of PCR. The concentration of $\mathrm{MgCl}_{2}$ was varied from 0 to $4.0 \mathrm{mM}$ with increments of $0.5 \mathrm{mM}$. No amplification occurred at $0.0 \mathrm{mM} \mathrm{MgCl}$. The amplification yield decreased with an increase in magnesium ion concentration beyond $2 \mathrm{mM}$ with the optimum concentration ranging between 1.0 and 2.0 $\mathrm{mM}$. The concentration of $1.5 \mathrm{mM}$ was used in the optimisation of primer concentration, which then produced the concentration of $125 \mathrm{ng}$ as the minimum, efficient concentration of each primer.

Optimisation of cycling conditions was performed with $1.5 \mathrm{mM} \mathrm{MgCl}_{2}$ and $125 \mathrm{ng}$ primers each. Amplification occurred at all annealing temperatures from 55 to $65^{\circ} \mathrm{C}$ indicative of high homology of the primers to the target region of the invA gene of Salmonella. The annealing conditions that produced the highest yield were $60^{\circ} \mathrm{C}$ and $30 \mathrm{~s}$ and were therefore adopted as the optimum primer annealing conditions.

In this study, amplification occurred efficiently without the extension phase when different extension periods ( 0 to $300 \mathrm{~s}$ ) were tested. However, an extension phase may be helpful in early cycles of PCR when the template concentration is low and at late cycles when the product concentration exceeds the enzyme concentration. Thus, a $1 \mathrm{~min}$ incubation period, which also resulted in a higher PCR yield, was adopted as optimal. The optimised PCR protocol is as follows: PCR buffer, 1.5U Taq DNA polymerase, $125 \mathrm{ng}$ primer each and $100 \mu \mathrm{M}$ of each dNTPs. The cycling conditions were $94^{\circ} \mathrm{C}, 1 \mathrm{~min} ; 60^{\circ} \mathrm{C}, 30 \mathrm{~s}$ and $72^{\circ} \mathrm{C}, 1 \mathrm{~min}$ followed by $7 \mathrm{~min}$ for the last cycle.

Limit of detection. The detection limit of Salmonella following optimisation of the PCR assay was $2.6 \times 10^{4} \mathrm{cfu} / \mathrm{m} \ell$ (Fig. 1, Lane 4) without any pre-enrichment step. The sensitivity was further increased to $26 \mathrm{cfu} / \mathrm{m} \ell$ (Fig. 1, Lane 7') following a $6 \mathrm{~h}$ pre-enrichment step prior to PCR.

Total DNA dilution. Serial dilutions of total DNA from S. enteritidis gave $300 \mathrm{pg} / \mathrm{m} \ell$ ( $1.5 \mathrm{pg} /$ reaction) as the minimal amount of template DNA required for positive amplification.

Specificity. The pair of primers used in this study showed to be specific to all salmonellae tested except the strain S. pullorum (Fig. 2a, Lane 12) and S. arizonae (Fig. 2a, Lane 13). Non- 


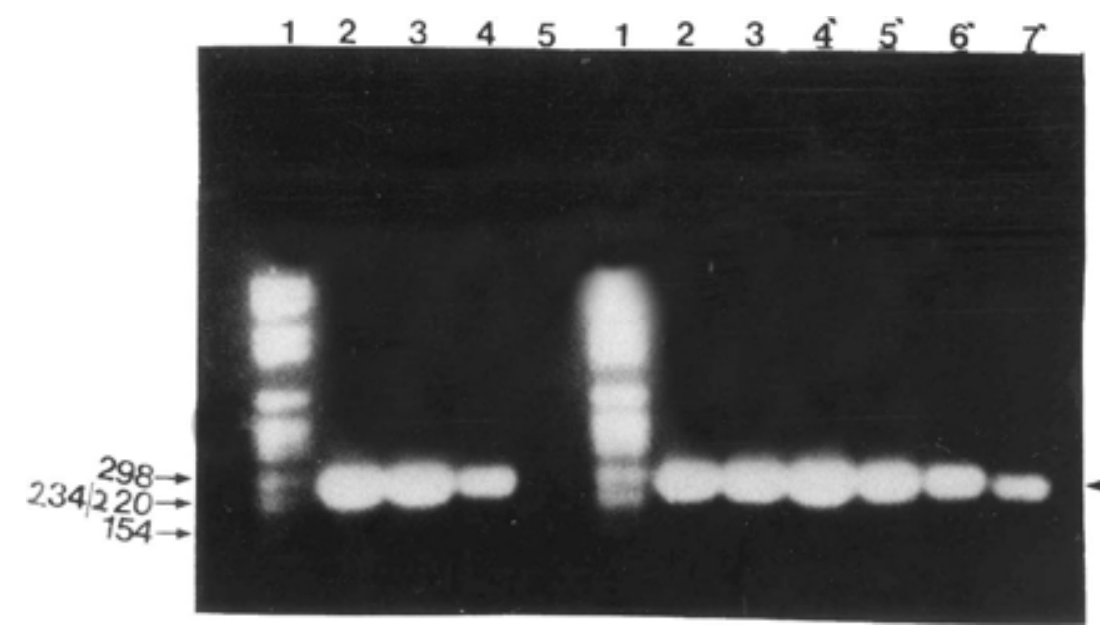

Figure 1

The detection limit of Salmonella cells. Amplification products were electrophoresed on a $1.5 \%$ agarose gel containing ethidium bromide. The values on the left are the molecular weight standards and on the right is the size of the target fragment in bp. Lanes without/ with a cap are amplification products obtained prior/after pre-enrichment, respectively. Lanes 1 and 1', 154bp DNA

-284 ladder; 2 and 2'- $2.6 \times 10^{6} \mathrm{cfu}$ $\mathrm{ml} ; 3$ and 3'-2.6 $\times 10^{5} \mathrm{cfu} / \mathrm{ml}$; 4 and 4'- $2.6 \times 10^{4} \mathrm{cfu} / \mathrm{ml} ; 5$ and 5'- $2.6 \times 10^{3} \mathrm{cfu} / \mathrm{ml} ; 6^{\prime}-2.6$ $\times 10^{2} \mathrm{cfu} / \mathrm{ml}$ and 7 '- $26 \mathrm{cfu} / \mathrm{ml}$.

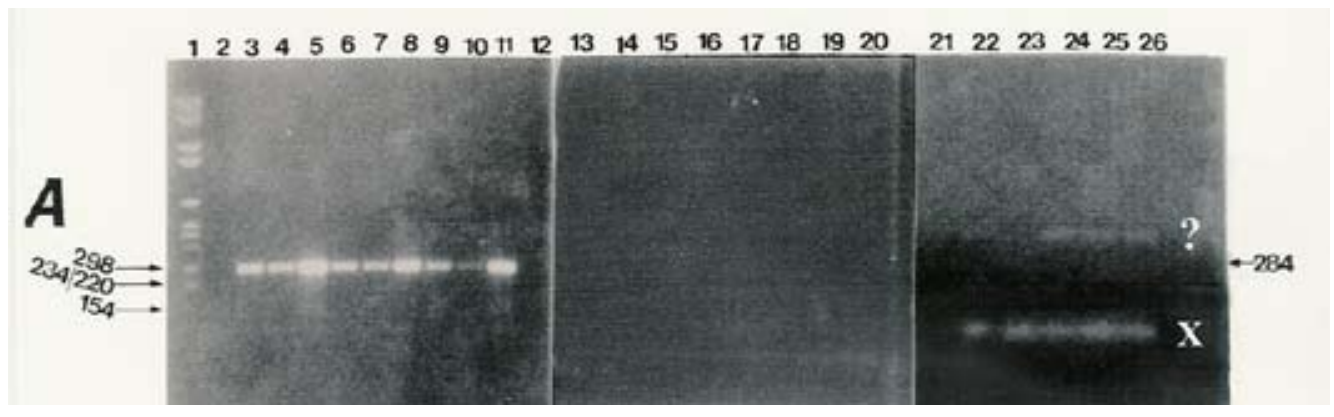

Figure 2A

The specificity of the invA primers tested by PCR on different related bacteria. Amplification products were electrophoresed in a 1.5\% agarose gel containing ethidium bromide. The values on the left of the picture are the molecular weight standards and on the right is the size of the target fragment in bp, the question mark (?) shows the non-specific amplification bands and X indicates PCR artifacts. Lanes 1, 154 bp DNA ladder; 2- negative control; 3- S. enteritidis; 4- S. saintpaul; 5- S. dublin; 6- S. typhi; 7- S. paratyphi; 8- S. typhimurium; 9- S. oxford; 10- S. bloemfontein; 11- S. derby; 12- S. pullorum; 13- S. arizonae; 14- E. coli O:112; 15- E. coli O:143; 16 - E. hermanii; 17- E. aerogenes; 18- B. cereus; 19- B. cereus var. mycoides; 20- S. dysentry;

21- S. sonnei; 22- S. flexneri; 23- S. boydii; 24- C. freundii; 25- K. pneumoniae; and 26- P. aeruginosa.

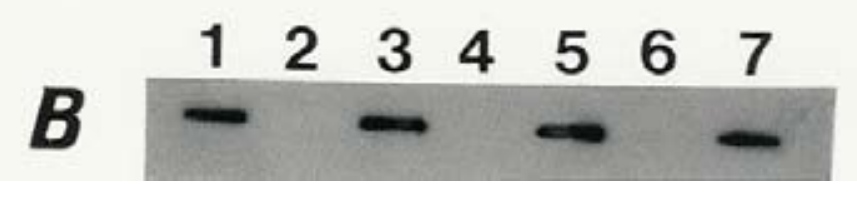

Figure 2B

Southern blot of a selected number of PCR products in A (gel not shown). Amplification products were hybridised to the internal Sal 3 probe. Lane 1- S. typhi; 2- C. freundii; 3- S. enteritidis; 4- K. pneumo-

niae; 5- S. typhimurium; 6- P. aeruginosa and 7- S. paratyphi.

specific amplification was occasionally observed with Klebsiella pneumoniae, Pseudomonas aeruginosa and Citrobacter freundii (Fig. 2a, Lanes 24-26) but the amplicon was slightly higher in molecular weight and showed weak amplification. Furthermore, the internal probe did not hybridise to the non-specific products (Fig. 2b). PCR artefacts (X) were occasionally observed.

Field samples. PCR detection efficiency of Salmonella was evaluated in parallel to the conventional culture method by testing waters collected from houses, communal taps, storage tanks and rivers. PCR was performed along each step of the culture method and Salmonella was detected in the presence of other bacteria in all the steps except prior to pre-enrichment. The selective/ differential media RV broth, XLD and BGA, did not inhibit the growth of non-Salmonella bacteria but the characteristic colonies of Salmonella on XLD and BGA were distinguishable from other non-Salmonella bacterial colonies.

The three areas, i.e., Kgapane, Mamabolo and Venda receive their water from different sources that are treated independently of each other. The water treatment was effective in reducing the amount of bacterial contamination and eliminating Salmonella from the water as evidenced by both the MPN values and PCR results of the tap waters collected in these 


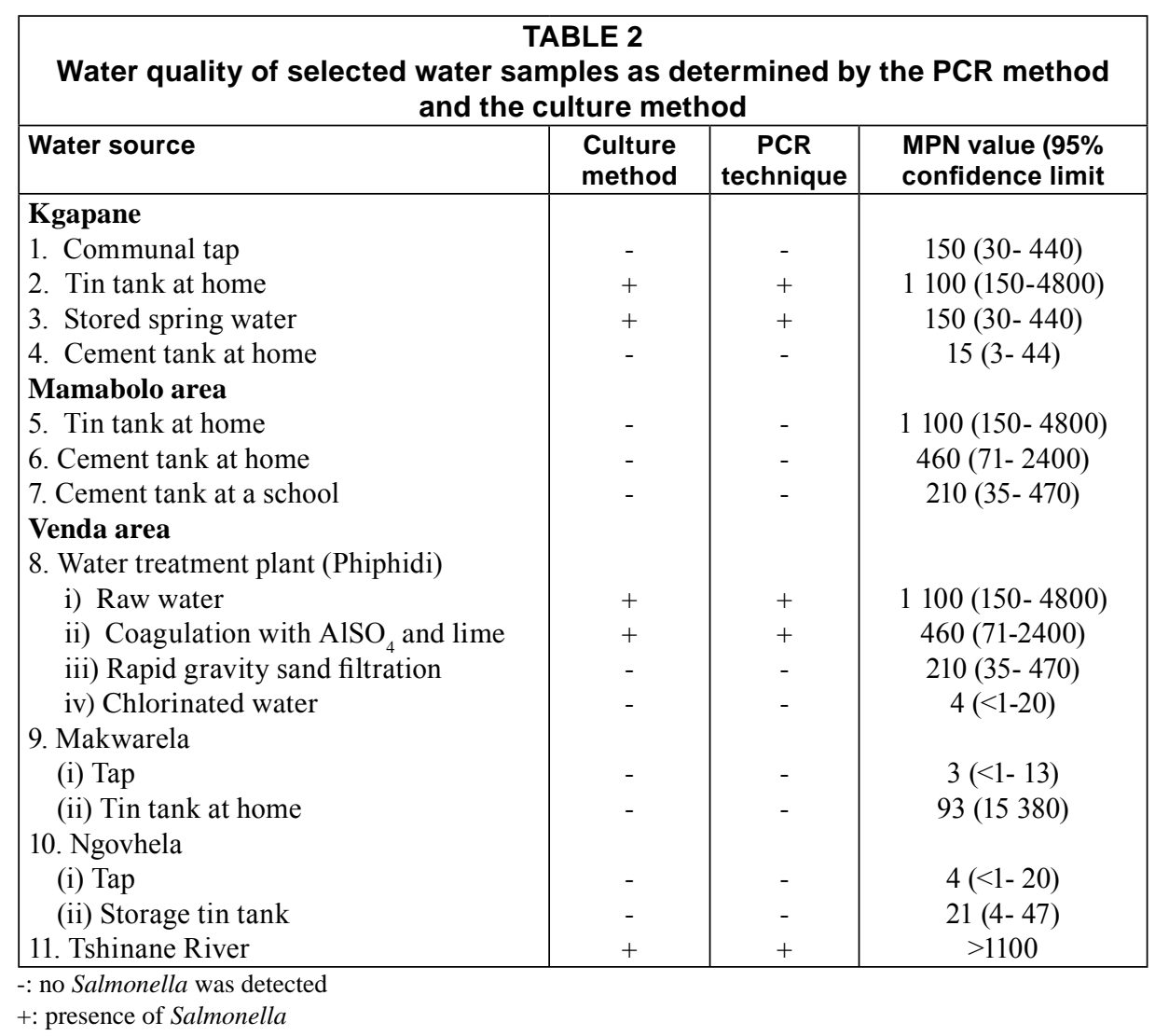

areas. Samples from the rivers exhibited high bacterial contamination as revealed by both PCR and the culture methods (Table 2).

Salmonella was detected by PCR in samples high in competing bacteria as determined by their MPN values. A high amount of indicator bacteria (coliform MPN index $>5$ ) did not necessarily coincide with the presence of Salmonella (Table 2). No false positives or negatives for Salmonella were observed with PCR when assaying field samples as confirmed by the culture method.

\section{Discussion}

The major objective of this study was to develop a rapid and reliable method for the detection of Salmonella in water from various sources. The PCR technique was improved by adjusting the concentrations of magnesium ions and primers as well as other cycling parameters to their optimal levels. Taq polymerase requires a divalent ion such as $\mathrm{Mg}^{2+}$ for activity, i.e.; $\mathrm{Mg}^{2+}$ serves as a cofactor and forms soluble complexes with dNTPs to produce the actual substrate that the polymerase recognises (PCR Applications Manual, 1999). Hence, no amplification occurred when $\mathrm{MgCl}_{2}$ was not added to the PCR mixture. The concentration of primers and the annealing conditions also affect the specificity of PCR. High primer concentrations and low annealing temperature allow mis-priming, the products of which will actively compete with the target sequence for primers. In the present study amplification occurred at an annealing temperature of as high as $65^{\circ} \mathrm{C}$ using Sal 1 and Sal 2 primers with Tms of $78^{\circ} \mathrm{C}$ and $68^{\circ} \mathrm{C}$, respectively. Adjusting the PCR components and the cycling parameters resulted in a progressive increase in amplification yield indicating that the concentrations of magnesium ions, primers and the cycling parameters all affected the fidelity of Taq polymerase and PCR yield. It is conceivable that further optimisation may still be possible by testing a high number of combinations of PCR parameters.

The limit of detection of the optimised PCR method was $2.6 \times 10^{4} \mathrm{cfu} / \mathrm{m} \ell$. Incorporation of a $6 \mathrm{~h}$ non-selective pre-enrichment step further increased the detection limit to $26 \mathrm{cfu} / \mathrm{ml}$. Similar results have been reported previously by other authors (Bej et al., 1994; Ellingson et al., 2004; Fratamico, 2003; Guo et al., 2000; Myint et al., 2006; Oliveira et al., 2002; Patel et al., 2006; Pan and Liu, 2002; Soumet et al., 1994) who observed that at least $10^{3}$ to $10^{5}$ cells $/ \mathrm{m} \ell$ must be present to give positive results by PCR without a pre-enrichment step and that 1 to 10 cells $/ \mathrm{m} \ell$ could be detected after a pre-enrichment step.

The target invA sequence is conserved among the tested species of Salmonella except for S. pullorum and S. arizonae that gave no amplification results. The absence of PCR products upon invA amplification of $S$. pullorum is in contradiction to a report by Galan et al. (1992) that this species tested positive for the presence of invA operon. S. pullorum is a host-specific avian pathogen and is often avirulent in mammals. S. pullorum lacked the ability to invade cultured mammalian epithelial cells when tested for invasiveness (Henderson et al., 1999). Thus, S. pullorum poses no possible danger to humans. Galan and Curtiss III (1991) clearly showed that the strains of S. arizonae may have significant alterations in the inv locus including the absence of some of the genes because they lack the ability to enter cultured epithelial cells (Galan et al., 1992). This deficiency was partially corrected upon addition of a plasmid containing the inv locus of S. typhimurium (Rahn et al., 1992). Thus, this strain also poses no danger to human beings. Non-specific amplification was occasionally observed with $K$. pneumoniae, $P$. aeruginosa and $C$. freundii, but the amplicons were found to be slightly higher in molecular weight than the targeted $284 \mathrm{bp}$ fragment and did not hybridise to the invA internal probe when tested (Fig. 2b). Rahn et al. (1992) observed similar non-specific amplicons when 
K. pneumoniae, $P$. aeruginosa were amplified.

No Salmonella was detected from direct PCR when environmental waters were assessed. Salmonella was detectable by PCR only after enrichment. Myint et al. (2006) observed similar results without pre-enrichment. All the samples tested that contained Salmonella according to the culture method showed positive amplification with PCR. No correlation was observed between the occurrence of Salmonella and MPN values of the environmental samples (Table 2). The major obstacles of using the PCR technique for direct detection of pathogens in environmental samples are the presence of PCR-inhibitory substances (Feder et al., 2001; Olsen et al., 1995; Picard et al., 1992; Straub et al., 1995; Tebbe and Vahjen, 1993; Tsai and Olson, 1992), the possibility of detecting dead cells (Olsen et al., 1995), and the large amount of start-up material that is required to obtain enough template for PCR (Knight et al., 1990, Sandery et al., 1996). The inclusion of a cultivation step prior to PCR that involved a tenfold dilution of the sample with medium eliminates the effect of PCR-inhibiting substances on amplification while increasing the number of detectable culturable Salmonella. In the past, the presence of various forms of waterborne pathogens was established by using methods that are reliable in detecting bacterial indicator organisms such as E. coli in water. McCambridge and McMeekin (1981) clearly showed that $E$. coli is more susceptible to light-induced decay and predation than S. typhimurium and other enteric bacteria, which may be a contributing factor to the poor correlation observed in this study. Although it was not observed in water samples tested in this study, pathogens have been detected in waters that have been considered safe on the basis of coliform bacteria (Morinigo et al., 1990).

Waterborne salmonellosis has significantly affected many rural people in South Africa during the past years (Department of Health, 1998). The unavailability of potable water leads to poor hygienic practices as people tend to minimise water usage and use dirty water, flowing and stagnant stream waters for drinking, bathing and laundry. Of the RSA population of 48.61 million, $7 \%$ has no infrastructure for provision of potable water and $10 \%$ has access below RDP level (Water Services: National Information System, 2006). In the Limpopo Province 7.5\% of the population lacks infrastructure to safe water while $21 \%$ has access below RDP level (Water Services: National Information System, 2006). This shortage of safe piped water leads to storage of water in open tanks and usage of surface water for domestic purposes (Central Statistical Service Report, 1997). The danger of the shortage of running tap water is supported by the report that communities in the Bochum area of Limpopo Province that used water from the Crocodile River suffered from repeated bilharzia and typhoid fever outbreaks (Chauke, 1996). Fincham and Dhansay (2006) reported bilharzia infections in $80 \%$ of children in Limpopo in 2005. The Sekhukhune district of Limpopo Province has reported 93 typhoid fever cases in 2004 (National Institute for Communicable Diseases, 2004), and Mpumalanga encountered an outbreak in 2006 (The Water Wheel, 2005). This trend shows than an urgent intervention to thoroughly monitor bacterial contamination of water systems is required to circumvent any possible human infections.

This study showed high prevalence of bacterial contamination including Salmonella in surface and stored waters while running tap water exhibited low coliform count and absence of Salmonella (Table 2). This observation infers enterobacterial contamination of water during storage either due to aerosols from dust that contains soil and dried animal excreta due to lack of ground cover and sanitary facilities or from persons that dip their contaminated hands into the storage containers to collect water. A similar observation was made in the dry Bochum area of RSA where Salmonella was mostly absent from the treated tap water while the stored water had high coliform counts (Chauke, 1996). Nonetheless, the quality of the drinking water tested in these three areas of the Limpopo Province, on average, does not conform to the South African Drinking Water Standard that allows 1 faecal coliform per $100 \mathrm{~m} \ell$ of sample (SANS 241, 2005). The implementation and expansion of water and sanitation infrastructure and management thus remain urgent for most rural households in RSA.

PCR offers a great diagnostic tool in comparison to the culture method based on the amount of time required to confirm the presence/absence of Salmonella. When optimised, PCR affords high specificity and sensitivity even in the presence of high levels of competing micro-organisms as evident from the MPN values of the samples (Table 2). However, in order to meet the standard detection limits for water quality (SANS 241, 2005), a pre-cultivation step is still required to increase sensitivity and to remove inhibitory substances when monitoring environmental samples. Some authors reported the existence of viable but non-culturable (VBNC) bacteria in environmental samples (Kjelleberg et al., 1993; Knight et al., 1990; Pommepuy et al., 1996 and Roszak and Colwell, 1987), which would not be enriched in a pre-cultivation step and thus may escape detection. Medema et al. (1992), Caro et al. (1999) and Smith et al. (2000) reported a loss of pathogenicity associated with non-culturability of S. typhimurium when subjected to seawater stress, solar and ultraviolet-C irradiation. Although the cultivation step excludes the detection of VBNC Salmonella, such bacteria most probably pose no significant threat to humans because of the minimum infectious dose of Salmonella $\left(10^{5} / 10^{9}\right.$ for $S$. typhi/ S. typhimurium respectively) required to initiate a disease (Le Minor, 1981). Thus, the $12 \mathrm{~h}$ cultivation-PCR assay offers a good diagnostic tool for the routine monitoring of Salmonella contamination in water used for domestic purposes in contrast to the $102 \mathrm{~h}$ culture method.

\section{Acknowledgements}

The authors thank the CSIR for funding this project and Mr HP Chabalala for providing statistical records from the Department of Health.

\section{References}

BEJ AK, MAHBUBANI MH, BOYCE MJ and ATLAS RM (1994) Detection of Salmonella spp. in oyster by PCR. Appl. Environ. Microbiol. 60 368-373.

BERGEY'S MANUAL OF SYSTEMATIC BACTERIOLOGY (19841989) Vols. 1-4. Baltimore, William and Wilkins.

CARO A, GOT P, LESNE J, BIRNARD S and BALEUX B (1999) Viability and virulence of experimentally stressed non-culturable Salmonella typhimurium. Appl. Environ. Microbiol. 65 3229-3232.

CARUSO G, ZACCONE R and CRISAFI E (2000) Use of indirect immunofluorescence method for detection and enumeration of Escherichia coli in seawater samples. Lett. Appl. Microbiol. 31 274-278.

CENTRAL STATISTICAL SERVICE (CSS), RSA (1997) Statistical release P0317, P0317.1, P0317.5, P0317.7, P0317.8 and P0317.9.

CHAUKE LK (1996) Water and its Management in the Northern Bochum District, Northern Province, South Africa. Honours dissertation submitted to the Department of Microbiology, University of the North, Sovenga, RSA.

CHEN J and GRIFFITHS MW (2001) Detection of Salmonella and simultaneous detection of Salmonella and shiga-like toxin-producing Escherichia coli using the magnetic capture hybridisation polymerase chain reaction. Lett. Appl. Microbiol. 32 7-11. 
CHEN C and DURST RA (2006) Simultaneous detection of Escherichia coli O157:h7, Salmonella spp. and Listeria monocytogenes with an array-based immunosorbent assay using universal protein G-liposomal nanovesicles. Talanta 69 232-238.

DEPARTMENT OF HEALTH (RSA) (1998) Statistical Notes. Chief Directorate: Health Information, Evaluation and Research. Health Syst. Res. Epidemiol. p 3.

DIG SYSTEM USER'S GUIDE FOR FILTER HYBRIDIZATION (1995) Boehringer Mannheim.

ELLINGSON JLE, ANDERSON JL, CARLSON SA and SHARMA VK (2004) Twelve-hour real-time PCR technique for the sensitive and specific detection of Salmonella in raw and ready-to-eat meat products. Mol. Cell. Probes. 18 51-57.

FEDER L, NIETFELD JC, GALLAND J, YEARY T, SARGEANT JM, OBERST R, TAMPLIN ML and LUCHANSKY JB (2001) Comparison of cultivation and PCR-hybridization for detection of Salmonella in Porcine faecal and water samples. J. Clin. Microbiol. 39 2477-2484.

FINCHAM J and DHANSAY A (2006) Worms in SA's children. MRC Policy Brief. 2

FRATAMICO PM (2003) Comparison of culture, polymerase chain reaction (PCR) TaqMan Salmonella and Transia card Salmonella assays for detection of Salmonella spp. in naturally-contaminated ground chicken, ground turkey and ground beef. Mol. Cell. Probes. 17 215-221.

GALAN JE and CURTISS III R (1991) Distribution of the invA, B, C and $D$ genes of Salmonella typhimurium among other Salmonella serovars: invA mutants of Salmonella typhi are deficient for entry into mammalian cells. Infect. Immun. 59 2901-2908.

GALAN JE, GINOCCHIO C and COSTEAS P (1992) Molecular and functional characterization of the Salmonella invasion gene invA: Homology of invA to members of a new protein family. J. Bacteriol. 174 4338-4349.

GERICKE M and KFIR R (1995) Rapid Detection of Salmonella spp. in Water Using the Polymerase Chain Reaction. Division of Environmental, Water and Forestry Technology. CSIR-Pretoria.

GUO X, CHEN J, BEUCHAT LR and BRACKETT ER (2000) PCR Detection of Salmonella enterica serotype Montevideo in and on raw tomatoes using primers derived from hilA. Appl. Environ. Microbiol. 66 5248-5252.

HENDERSON SC, BOUNOUS DI and LEE MD (1999) Early events in the pathogenesis of avian salmonellosis. Infect. Immun. 673580 3586

JARADAT ZW, BZIKOT JH, ZAWISTOWSKI J and BHUNIA AK (2004) Optimization of a rapid dot-blot immunoassay for detection of Salmonella enterica serovar Enteritidis in poultry products and environmental samples. Food Microbiol. 21 761-769.

KJELLEBERG S, FLARDT KBG, NYSTROM T and MORIARTY DJW (1993) Growth limitation and starvation of bacteria, pp308310. In: TE Ford (ed.) Aquatic Microbiology. London: Blackwell Scientific Publications.

KNIGHT IT, SHULTS S, KASPAR CW and COLWELL RR (1990) Direct detection of Salmonella spp. in estuaries by using a DNA probe. Appl. Environ. Microbiol. 56 1059-1066.

LE MINOR L (1981) The genus Salmonella. In: MP Starr, H Stolp, HP Truper, A Ballows and HG Schlegen (eds.) The Prokaryotes, A Handbook on Habit, Isolation, and Identification of Bacteria. Springer-Verlag. USA. 1148-1159.

LEHLOESA LJ and MUYIMA NYO (2000) Evaluation of the impact of household treatment procedures on the quality of groundwater supplies in the rural community of the Victoria district, Eastern Cape. Water SA 26 (2) 285-290.

LIU Y, CHE Y and LI Y (2001) Rapid detection of Salmonella typhimurium using immuno-optical sensing method. Sens. Actuators B. 72 241-218.

MANSFIELD LP and FORSYTHE SJ (2000) The detection of Salmonella using a combined immunomagnetic separation and ELISA end-detection procedure. Lett. Appl. Microbiol. 31279283.

MARMUR J (1961) A procedure for the isolation of DNA from organisms. J. Mol. Biol. 3 208-218.

McCAMBRIDGE J and MCMEEKIN TA (1981) Effects of solar radiation and predacious micro-organisms on survival of faecal and other bacteria. Appl. Environ. Microbiol. 41 1083-1087.

MEDEMA GJ, SCHETS FM, VAN DER GIESSEN AW and HAVELAAR AH (1992) Lack of colonization of 1-day old chicks by viable, non-culturable Campylobacter jejuni. J. Appl. Bacteriol. 72 512- 516

DE MEDICI D, PEZZOTTI G, MARFOGLIA C, CACIOLO D, FOSCHI G and OREFICE L (1998) Comparison between ICS-Vidas, MSRV and standard cultural method for Salmonella recovery in poultry meat. Int. J. Food Microbiol. 45 205-210.

MORINIGO MA, CORNAX R, MUNOZ MA, ROMERO P and BORREGO JJ (1990) Relation between Salmonella spp. and indicator micro-organisms in polluted natural waters. Water Res. 24 117-120.

MYINT MS, JOHNSON YJ, TABLANTE NL and HECKERT RA (2006) The effect of pre-enrichment protocol on the sensitivity and specificity of PCR for detection of naturally contaminated Salmonella in raw poultry compared to conventional culture. Food Microbiol. 23 599-604.

NATIONAL INSTITUTE FOR COMMUNICABLE DISEASES (2004) Communicable Diseases Communique. 3 (9)

NEVONDO TS and CLOETE E (2002) Assessing the cholera epidemic in South Africa. Lab. Mark. Spectrum 21 2-3.

OBI CL, POTGIETER N, BESSONG PO and MATSAUNG G (2002) Assessment of the microbial quality of river water sources in rural Venda communities in South Africa. Water SA 28 (3) 287-292.

OLIVEIRA SD, SANTOS LR, SCHUCH DM, SILVA AB, SALLE CT and CANAL CW (2002) Detection and identification of salmonellas from poultry-related samples by PCR. Vet. Microbiol. 87 25-35.

OLIVEIRA SD, RODENBUSCH CR, CE MC, ROCHA SL, CANAL CW (2003) Evaluation of selective and non-selective enrichment PCR procedures for Salmonella detection. Lett. Appl. Microbiol 36 217-221.

OLSEN JE, AABO S, HILL W, NOTERMANS S, WERNARS K, GRANUM PE, POPOVIC T, RASMUSSEN HN and OLSVIK $\varnothing$ (1995) Probes and polymerase chain reaction for detection of foodborne bacterial pathogens. Int. J. Food Microbiol. 28 1-78.

PAN TM and LIU YJ (2002) Identification of Salmonella enteritidis isolates by polymerase chain reaction and multiplex polymerase chain reaction. J. Microbiol. Immunol. Infect. 35 147-151

PATEL JR, BHAGWAT AA, SANGLAY GC and SOLOMON MB (2006) Rapid detection of Salmonella from hydrodynamic pressure-treated poultry using molecular beacon real-time PCR. Food Microbiol. 23 389-46

PCR APPLICATIONS MANUAL (1999) Roche Molecular Biochemicals.

PICARD C, PONSONNET C, PAGET E, NESME $X$ and SIMONET P (1992) Detection and enumeration of bacteria in soil by direct DNA extraction and polymerase chain reaction. Appl. Environ. Microbiol. 58 2717-2722.

POMMEPUY M, BUTIN M, DERRIEN A, GOURMELON M, COLWELL RR and CORMIER M (1996) Retention of enteropathogenicity by viable but non-culturable $E$. coli exposed to seawater and sunlight. Appl. Environ. Microbiol. 62 4621-4626.

RAHN K, DE GRANDIS SA, CLARKE RC, McEWEN SA, GALAN JE, GINOCCHIO C, CURTISS III R and GYLES CL (1992) Amplification of an invA gene sequence of Salmonella typhimurium by polymerase chain reaction as a specific method of detection of Salmonella. Mol. Cell. Probes 6 271-279.

ROSZAK DB and COLWELL RR (1987) Survival strategies of bacteria in the natural environment. Microbiol. Rev. 51 365-379.

SAMBROOK J, FRITSCH EF and MANIATIS T (1989) Molecular Cloning, a Laboratory Manual. Vols. 1, 2 and 3. ( $2^{\text {nd }}$ edn.) Cold Spring Harbor Laboratory Press. USA.

SANDERY M, STINEAR T and KAUCNER C (1996) Detection of pathogenic Yersinia enterocolitica in environmental waters by PCR. J. Appl. Bacteriol. 80 327-332.

SANS 241 - SOUTH AFRICAN NATIONAL STANDARDS (2005) Drinking Water. Republic of South Africa.

SANS 6340 - SOUTH AFRICAN NATIONAL STANDARDS (2004) Water Quality - Detection of Salmonella Species. Republic of South Africa.

SANS 8199 - SOUTH AFRICAN NATIONAL STANDARDS (2006) Water Quality - General Guidance on the Enumeration of Micro- 
Organisms by Culture. Republic of South Africa.

SCHRANK IS, MORE MAZ, COSTA JLA, FRAZZON APG, SONCINI R, SCHRANK A, VAINSTEIN MH and SILVA SC (2001) Influence of enrichment media and application of PCR based method to detect Salmonella in poultry industry products and clinical samples. Vet. Microbiol. 82 45-53.

SMITH RJ, KEHOE SC, MCGUIGAN KG and BARER MR (2000) Effects of simulated solar disinfection of water on infectivity of Salmonella typhimurium. Lett. Appl. Microbiol. 31 284-288.

SOUMET C, ERMEL G, FACH P and COLIN P (1994) Evaluation of different DNA extraction procedures for the detection of Salmonella from chicken products by polymerase chain reaction. Lett. Appl. Microbiol. 19 294-298.

SOUMET C, ERMEL G, ROSE N, ROSE V, DROUIN P, SALVAT $G$ and COLIN P (1999a) Evaluation of a multiplex PCR assay for simultaneous identification of Salmonella sp., Salmonella enteritidis and Salmonella typhimurium from environmental swabs of poultry houses. Lett. Appl. Microbiol. 28 113-117.

SOUMET C, BLIVET D, ERMEL G, COLIN P and SALVAT G (1999b) An immunoconcentration-PCR assay to detect Salmonella in the environment of poultry houses. Int. J. Food Microbiol 48 221-224.

STRAUB TM, PEPPER IL and GERBA CP (1995) Removal of PCRinhibiting substances in sewage sludge amended soil. Water Sci. Technol. 31 311-315.

TEBBE CC and VAHJEN W (1993) Interference of humic acids and DNA extracted directly from soil in detection and transformation of recombinant DNA from bacteria and a yeast. Appl. Environ. Microbiol. 59 2657-2665.

THE WATER WHEEL (2005) Water Research Commission, RSA. November/ December Publication 4 (6).

THE WATER WHEEL (2006) Water Research Commission, RSA. September/ October Publication 5 (5).

TSAI Y and OLSON BH (1992). Rapid method for separation of bacterial DNA from humic substances in sediments. Appl. Environ. Microbiol. 58 2292-2295.

WALKER RL, KINDE H, ANDERSON RJ and BROWN AE (2001) Comparison of Vidas enzyme-linked fluorescent immunoassay using Moore swab sampling and conventional culture method for Salmonella detection in bulk tank milk and in-line milk filters in California dairies. Int. J. Food Microbiol. 67 123-129.

WALLACE DM (1987) Large- and small-scale phenol extractions. In: Berger SL and AR Kimmel (eds.) Methods in Enzymology 152 Guide to Molecular Cloning Techniques. Academic: Press, Inc. London. 33-48

WANG SJ and YEH DB (2002) Designing of polymerase chain reaction primers for the detection of Salmonella enteritidis in foods and faecal samples. Lett. Appl. Microbiol. 34 422- 427.

WATER SERVICES: NATIONAL INFORMATION SYSTEM (WS NIS) http://www.dwaf.gov.za/dir_ws/wsnis/toolbox/pg_Reports. asp?SAID $=238 \&$ SASID $=545 \&$ curPerspectiveID $=2 \& \mathrm{fa}=$ homepage. homepage \&curNavViewID $=0$ (Accessed 20/11/2006). 